\title{
PERCAMPURAN BUDAYA JAWA DAN CINA: Harmoni dan Toleransi Beragama Masyarakat Lasem
}

\author{
Ahmad Atabik \\ Program Doktor Universitas Islam Negeri Walisongo
}

\begin{abstract}
This article explores the fact of harmony and religious tolerance values of the culture assimilation of Tionghoa ethnic dan local people in Lasem. Tionghoa ethnic have lived in Lasem since XI Century. Their existence bear new culture and plurarity for Lasem people that leads to a religiocity and social harmony within the people. The harmonius relation is proven when their both fight against Dutch Collonials in Lasem. The harmonious and tolerance of Lasem moslems can be seen in the interaction of the local people and the newcomer (Tionghoa ethnic), whether they are muslim or not.
\end{abstract}

Keywords: Culture, Harmony, Religious Tolerance

\section{Pendahuluan}

Lasem mempunyai sejarah panjang toleransi dan harmonisasi antara penduduk asli dengan para pendatang etnis Tionghoa. Sebagai kota kecil, Lasem telah membuktikan tumbuh suburnya sikap toleransi di kalangan masyarakat Jawa sebagai pribumi dengan kelompok masyarakat Cina sebagai pendatang. Percampuran kedua etnis tersebut tampak dalam berbagai sektor kehidupan, terutama bidang ekonomi dan sosial. Bahkan saat bangsa ini berjuang melawan penjajah Belanda, di Lasem kedua kelompok masyarakat tersebut bahu membahu bertempur bersama melawan penjajah.

Pluralitas masyarakat Lasem telah membentuk sebuah harmonisasi kerukunan umat beragama. Penduduk asli Lasem sangat menghormati adat-istiadat dan kebudayaan masyarakat Cina. Sebagaian besar dari masyarakat Lasem memeluk Islam, sebagian kecil lain beragama Kristen dan Budha sebagai kepercayaan Tuhan Yang Maha Esa. Dalam silang budayanya, masyarakat keturunan Cina di Lasem sangat menghormati adat istiadat penduduk jawa sebagai pribumi, begitu juga hal yang sama dilakukan penduduk Jawa, sehingga terjalinnya hubungan yang baik dan erat antara etnis Cina di Lasem dengan penduduk asli Jawa.

Percampuran budaya antara etnis Tionghoa dan penduduk pribumi Lasem terbentuk dalam struktur sosial yang saling membutuhkan. Relasi ini terjadi pada wilayah elit dan masyarakat di perkampungan pada kehidupan seharihari. Pola hubungan antarelit terjadi pada komunikasi bersama dalam negosiasi, kontestasi maupun relasi yang saling membutuhkan. Negosiasi antarelit tampak pada kesempatan damai yang terjadi di Lasem untuk mengamankan kota pada isu kekerasan yang terjadi di akhir pemerintahan orde Baru (Aziz, 2014: 146).

Berangkat dari view point di atas, penulis bermaksud mengeksplorasikan sebuah fakta tentang percampuran budaya antara etnis Tionghoa dan pribumi Jawa yang terjadi di Lasem. Mula-mula penulis menjelaskan tentang fakta sejarah awal mula kedatangan etnis Cina di Lasem, serta hubungan yang harmonis antara kedua etnis tersebut terutama ketika bersama-sama melawan penjajah Belanda di bumi Lasem. Diakhir juga 
dieksplorasikan tentang nilai-nilai harmonisasi dan toleransi masyarakat muslim Lasem dengan pendatang baik sesama muslim dengan yang non muslim terutama dengan etnis Cina.

\section{Sekilas tentang Masyarakat Lasem}

Lasem merupakan kota kecil yang secara admistrasi termasuk dalam wilayah Kabupaten Rembang, sekitar 110 $\mathrm{Km}$ dari Semarang ke arah timur, sepanjang jalur pantura. Terletak $12 \mathrm{~km}$ sebelum timur kota Rembang. Wilayahnya berada di tengah-tengah jalur utama Pantura-antara Semarang dan Surabaya (Unjiya, 2015: 1). Seperti halnya dengan kota-kota pantai utara Jawa yang pernah mengalami kejayaannya di masa lampau, Lasem juga mempunyai elemen pendukung kota seperti: sungai (sungai Bagan), pelabuhan yang mudah didarati oleh kapal-kapal dari ukuran kecil sampai sedang serta jalan raya yang menghubungkan kota ini dengan kota-kota besar lainnya di Jawa (Handinoto, 2015: 6).

Pada awal abad ke-14, kota kecil Lasem merupakan salah satu kekuasaan Kerajaan Majapahit. Kerajaan ini telah ada di Indonesia sejak abad ke-13 sampai abad ke-15. Dan mulai runtuh ketika Islam datang ke Indonesia. Tome Pirres, seorang pengelana Portugis, mencatat bahwa dari wilayah Rembang ke arah timur sampai wilayah Tuban, terkenal sebagai pengrajin kayu (Handinoto, 2015: 6-7). Salah satu sumber berita mengenai kecamatan itu, menyebut Lasem telah menjadi semacam tanah bawahan Majapahit pada tahun 1273 Saka atau 1351 Masehi. Wilayah ini dipimpin oleh perempuan bernama Dewi Indu yang merupakan kemenakan Prabu Hayam Wuruk, penguasa Majapahit (Kamzah, 1858) (http://suaramerdeka.com).

Sumber lain menyebutkan Lasem pernah menjadi kadipaten di bawah kerajaan Islam Demak melalui kepemimpinan Raden Patah yang berhasil "menggeser" otoritas Majapahit. Pada Tahun 1751 Lasem ditetapkan sebagai kecamatan setelah setahun sebelumnya status kota kabupaten dipindahkan ke Rembang oleh pemerintah kolonial Belanda. Dari seluruh keragaman yang hadir, aroma Cina adalah paling kuat seperti umumnya daerah pesisir utara Jawa semenjak abad ke-15. Hingga hari ini cukup mudah menemukan ornamenornamen Cina pada bangunan kuno di kecamatan tersebut. Sentuhan perpaduan ini tentu merupakan hasil dari penghargaan masyarakat Lasem atas keragaman mereka (Hartono dan Handinoto, 2006).

Bahkan di Lasem terdapat Kelenteng Bie Yong Gio, kelenteng yang mempunyai sejarah panjang etnis Tionghoa di Lasem yang kerap disebutsebut sebagai simbol akan pluralitas. Kelenteng ini menurut cerita dipersembahkan kepada tiga tokoh utama yang berasal dari etnis Tionghoa yang berjasa bagi Lasem, terutama dalam melawan kolonialisasi VOC Belanda dalam perang yang dakhsyat yaitu Perang Kuning. Ketiganya adalah Oey Ing Kyat, Tan Kie Wie, dan Raden Panji Margono (Unjia, 2014: 2-5).

\section{Asal Usul Permukiman dan Budaya Cina di Lasem \\ 3.1. Kedatangan Orang-orang Cina di Lasem \\ Pada awal abad pertama orang} Cina telah datang di nusantara. Beberapa sumber dari Cina menjelaskan bahwa Cina telah mengenal Jawa sejak awal abad pertama Masehi. Hal tersebut ditunjukkan oleh catatan Cina tentang terdamparnya pendeta Budha, Fa Hsein yang sering disebut Fa Hian/Fa Man dan Hwui Ning disebuah pulau bernama "YaWa-Di". Ya-Wa-Di adalah transliterasi Cina dan toponim Jawadwipa dalam teks Sansekerta. Selain itu, sejumlah benda prasejarah yang ditemukan di Indonesia menunjukkan terjadinya interaksi bangsa 
Cina Nusantara (Komunitas Rumah Buku Lasem, 2014: 23).

Kedatangan orang-orang Cina di nusantara pada umumnya adalah para pedagang. Para pedagang ini mengunjungi pelabuhan-pelabuhan di berbagai kota pantai Utara Jawa. Beberapa pedagang Cina tersebut ada yang menetap di Jawa, yang kemudian terasimilasi secara permanen. Di Lasem diperkirakan pada abad ke-11 sudah terdapat permukiman yang permanen orang Cina di sebelah timur di tepi Sungai Lasem. Umumnya mereka menikahi wanita setempat dan kemudian memilih menetap selamanya di tanah baru tersebut (Hantinoto, 2015: 15).

Kedatangan mereka ke pulau Jawa dapat diketahui dari perjalanan yang dilakukan oleh Laksaman Cheng Ho ke berbagai wilayah di pulau Jawa pada awal abad ke-14. Kapal-kapal yang berlayar dari negara-negara asing, termasuk Cina yang mendarat di Tuban, Gresik dan Majapahit. Pada masa itu, Lasem termasuk bagian dari kekuasaan Majapahit. Hal ini menyebabkan Lasem menjadi tempat tinggal bagi beberapa orang Cina yang bekerja sebagai penjaga gerbang, orang sampan maupun pedagang. Kedatangan mereka ini di Lasem, sontak melahirkan kebudayaan baru. Kebudayaan ini merupakan intisari dari adat-istiadat Cina yang kemudian diadopsi menjadi adat daerah yang tidak luntur dari budaya Tionghoa sendiri. Hal ini disebabkan adanya komunikasi yang baik dari masyarakat lokal dengan masyarakat Tionghoa. Respek masyarakat Jawa terhadap orang-orang Cina disebabkan anggapan bahwa masyarakat Cina sebagai pedagang yang ulet dan terampil sehingga banyak pedagang lokal yang meniru. cara berdagang masyarakat Cina (Komunitas Rumah Buku Lasem, 2014: 24).

Para imigran Cina yang telah menetap selama lebih dari dua atau tiga generasi dan berbaur dengan penduduk
Lasem menjadi terbiasa dengan bahasa dan adat istiadat di mana mereka berada. Hal ini tercermin dalam berbagai aspek kesenian Jawa di Lasem. Pengaruh dalam kesenian Jawa tampak pada seni batik, khususnya pola dan ragam hias dan warna yang digunakan seperti dapat dijumpai pada baik tulis Lasem. Sebagian dari orang Cina yang berasal dari keturunan Cina dan telah melakukan perkawinan silang dengan penduduk Jawa, kemudian ada yang berkembang menjadi ahli seni dan pelindung kesenia Jawa (Komunitas Rumah Buku Lasem, 2014: 25).

Perkembangan masyarakat Cina di Indonesia meningkat pesat sejak terjadi gelombang migrasi pada abad ke-19. Seiring perkembangan zaman, dikarenakan adanya pembagian stratifikasi sosial berdasarkan kriteria ras, maka keberbedaan etnis Cina membentuk suatu kelompok masyarakat yang bertempat tinggal dalam satu kawasan yang disebut "Kampoeng Pecinan". Etnis kawasan Pecinan Lasem mempunyai keunikan, karena memiliki kebudayaan, kepercayaan dan Agama dan berbeda dengan masyarakat pribumi atau Jawa, mereka membuat wilayah atau kawasan yang terpisah dengan penduduk asli (Unjia, 2014: 15).

Di Lasem, penduduk asli sangat menghormati adat istiadat dan kebudayaaan masyarakat Cina. Bahkan sebagian besar dari mereka memeluk agama Islam, Kristen atau Budha sebagai kepercayaan Tuhan Yang Maha Esa. Dalam pembaurannya masyarakat Cina Lasem sangat menghormati adat istiadat penduduk asli, begitu juga hal yang sama dilakukan penduduk asli sehingga terjalinnya hubungan baik antara etnis Cina di Lasem dengan penduduk asli.

\subsection{Transformasi Permukiman Cina di Lasem \\ Para imigran Tionghoa yang datang ke Lasem tidak hanya berasal dari}


satu kelompok suku bangsa. Namun, mereka berasal dari berbagai suku bangsa di negeri Tiongkok dan tempatnya pun saling berjauhan atau terpisah. Misal, sebagian berasal dari suku Hokkian yang mendiami pemukiman Cina di Lasem berasal dari daerah Fukien Selatan dan merupakan imigran terbesar di Negaranegara Asia pada abad ke-19. Suku ini memiliki kepiawaian dalam berdagang dan etos kerja yang tinggi. Suku lain yang mendiami Lasem adalah suku bangsa Hokka yang berasal dari provinsi Guandong di bagian Cina selatan. Suku ini lebih suka merantau ke daerah seberang selatan. Suku lain yang membentuk pemukiman di Lasem adalah suku Tie Ciu dan Kwang Fu yang berasal dari pantai utara Cina, yaitu daerah pedalaman Swatow di bagian timur provinsi Kwantung (Komunitas Rumah Buku Lasem, 2014: 29).

Pada abad ke-18, kota Lasem yang punya penduduk Cina relatif banyak jika dibandingkan dengan daerah lain di Jawa. Pada tahun 1740-an ketika terjadi huru hara pembantaian orang Cina di Batavia, Lasem dan sekitarnya banyak menampung pelarian orang Cina dari Batavia. Hal ini mudah disadari karena mereka ini merasa senasib dengan sukunya. Sebaliknya, bagi pemerintah Belanda, kota ini justru dicurigai sebagai api dalam sekam. Sehingga kota Lasem dalam perkembangan selanjutnya terus diawasi dan sedapat mungkin ditekan untuk bisa berkembang. Sebagai tindakan nyata, kemudian ibukotanya dipindahkan ke Rembang pada tahun 1750, sehingga sejak saat itu Kota Lasem hanya sebagai kota kecamatan saja, sampai sekarang (Handinoto, 2015: 31).

Setelah ibukota kabupaten berpindah, perkembangan kota Lasem semakin lama semakin suram. Mulai dari pelabuhannya yang telah lama mati, sampai mata pencarian bagi etnis Cina yang semakin tidak menjanjikan (kecuali batik), berakibat pindahnya generasi mudanya ke kota-kota besar di Jawa terutama pada abad ke-20. Permukiman orang Cinanya (Pecinan) makin lama makin pudar tidak seperti kota-kota pantai utara Jawa lainnya, semisal Jakarta, Semarang, maupun Surabaya. Lambannya perkembangan kota Lasem mestinya punya sisi positif dari segi kota lamanya, karena hampir tidak mengalami modernisasi seperti halnya di kota-kota besar lainnya. Namun, dalam praktiknya kerana letaknya di jalan antara Ibu Kota Jawa Tengah dan Jawa Timur, maka mau tidak mau kota kecamatan ini juga mengalami imbasnya (Handinoto, 2015: 32).

\section{Harmoni interaksi Sosial Cina dengan Pribumi}

Sejarah telah mencatat adanya interaksi sosial antara masyarakat pribumi Lasem dengan etnis Cina, bahkan sejak abad 14 hingga abad 16 pasca gelombang migrasi Cina datang ke tanah Jawa pada masa Majapahit. Meskipun interaksi kedua etnis tersebut mengalami pasang surut, namun harmoni dan toleransi itu senantiasa berjalan dengan baik. Harmonisasi itu dapat dilihat dalam hal berikut ini:

\subsection{Bahu membahu melawan penjajah}

Kedatangan Belanda (VOC) ke tanah Jawa dalam pelayaran pertamanya pada tahun 1959 bertujuan membeli rempah-rempah yang dihasilkan pribumi. Namun tujuan awal yang mereka laksanakan akhir berbelok menjadi penjajahan. Perlawanan pribumi terhadap penjajah terdapat diberbagai daerah, demikian juga terjadi di Lasem.

Untuk mendapatkan monopoli dalam seluruh perdagangan di pantai utara Jawa, pada tahun 1979 mereka menyerang Lasem yang masih di luar pengaruh Belanda. Belanda yang didukung Amangkurat II yang merupakan boneka pemerintah Belanda di Mataram. Terjadi peperangan yang berlarut-larut 
dan hebat, hingga putra pertama Tejokusumo II yaitu Raden Mas Wingit, yang pada waktu itu menjadi penguasa Lasem terbunuh di tengah-tengah peperangan. Pada tahun 1714, Tedjokusumo V ditunjuk oleh Sunan Pakubuwono I menjadi Adipati Lasem. Tetapi Tedjokusumo V mengundurkan diri pada tahun 1727, beliau tidak setuju dengan hubungan erat antara Sunan dan Belanda. Kemudian menunjuk Oei Ing Kiat menjadi Tumenggung Lasem yang diberi nama Tumenggung Widyaningrat. Oey Ing Kiat adalah keturunan Bi Nang Oen, salah seorang juru mudi armada Laksamana Ceng Ho yang mendarat di Bonang-Lasem. Bi Nang Oen seorang pujangga dari Campa dan penyebar agama Islam di Lasem pada awal abad ke XV (Komunitas Rumah Buku Lasem, 2014: 70).

Sejarah perlawanan rakyat Lasem, kaum santri bersama etnis Cina melawan penjajah Belanda dimulai sejak zaman Amangkurat IV (1717-1726). Pada Tahun 1740 besar-besaran terhadap VOC yang dilakukan oleh orang Cina di Batavia, atau dikenal dengan peristiwa Angke yang menelan ribuan nyawa. Hal ini diakibatkan pembantaian orang Tionghoa di Batavia, kurang lebih 1.000 orang Tionghoa Batavia lari dan mengungsi di Lasem, Pada tahun 1741, akibat kerusuhan di Kartasura, Ngawi dan banyak kota di Jawa Tengah banyak orang Tionghoa mengungsi ke Lasem. Tumenggung Oei Ing Kiat menerima para pelarian Angke itu dan mengizinkan mereka membangun perkampunganperkampungan baru di tepi Sungai Kamandung (Karangturi), Pereng, dan Soditan (Unjiya, 2014: 169).

Pelarian Tionghoa Batavia pada umumnya berprofesi sebagai pedagang, pegawai pelabuhan, dan buruh kasar yang mempunyai karakter pekerja keras. Kedatangan mereka disambut baik oleh warga pribumi Lasem, terutama sesama etnis Cina. Akibatnya, pelabuhan di
Lasem kedatangan banyak tenaga buruh baru. Mereka bekerja menjadi pelabuhan, ada pula yang menjadi buruh tani, dan tambak milik para penduduk. Namun, semarak perubahan di Lasem itu tidak berlangsung lama, pergolakan kembali terjadi. VOC secara politik semakin kuat mulai membidik daerah Rembang, daerah dianggap strategis sebagai kawasan perdagangan dan hutannya yang luas menghasilkan jati yang melimpah (Unjia, 2014: 170-171).

Terdapat perjanjian antara Mataram dan VOC kala itu, VOC berhak dan berkuasa atas perekomendasian, pengangkatan maupun pemecatan pejabatpejabat kerajaan dan juga para adipati di pantai utara. Sesuai dengan perjanjian tersebut, kemudian VOC mendirikan pemerintahan regency dan kantor dagang di Rembang dan Jepara. Tindakan VOC itu dianggap oleh Tumenggung Widyaningrat Oei Ing Kiat telah mengikis teriotiral dan sekaligus sebagai ancaman serius bagi Kadipaten Lasem. Dengan diam-diam, Tumenggung Widyaningrat bersama Tan $\mathrm{Ke}$ Wie seorang pengusaha kaya keturunan Cina dan Raden Panji Margono yang tak lain adalah putra Tejakusuma $\mathrm{V}$ yang mempunyai pengaruh sangat besar, membangun kekuatan milisi bersama rakyat Lasem. Mereka merencanakan penyerbuan ke tangki VOC di Rembang, Juana dan Jepara (Unjia, 2014: 172).

Pertempuran antara pasukan milisi Dampoawang Lasem dan legion VOC Jepara hanya berlangsung di perairan sekitar Jepara saja. Lascar milisi Dampoawang Lasem tak mampu melawan hadapan pasukan legion VOC. Banyak kapal milisi Dampoawang Lasem yang hancur berantakan diterjang meriammeriam panas. Pimpinan pasukan Tan Ke Wie pun akhirnya gugur dalam pertempuran itu setelah kapal yang ditumpanginya terbakar hancur oleh hantaman meriam. Usai peristiwa tersebut, Tumenggung Widyaningrat 
menulis dalam sebuah prasasti namanama para korban yang meninggal dalam aksara Cina dan disembunyikan di Tambak Batok Mimi. Atas kekalahan pasukan Dampoawang Lasem, pada tahun 1743, kota Lasem diduduki oleh VOC. Kekuasaan pemerintah Kadipaten Lasem telah diambil alih (Unjia, 2014: 176).

Untuk menjalankan pemerintah baru di Lasem, pada tahun 1745 Gubernur Jendral VOC, Van Imhof, mengangkat Suro Adimenggolo III, seorang bangsawan dari semarang menjadi bupati di regency Lasem yang berkedudukan di Tulis, Selopuro. Namun, pemerintahan regency Lasem yang sesuai diharapkan VOC tak bisa berlangsung dengan baik. Rupanya kebencian dan sikap menolak rakyat Lasem terhadap keberadaan regency buatan VOC di Kadipaten Lasem menyebabkan tak kondusifnya keadaan. Gerakan-gerakan bawah tanah yang selama itu berada di hutan dan pegungungan melancarkan serangan-serangan tak terduga di regency Tulis dan tangsi Gebang. Namun karena pertimbangan keamanan pribadi dan kelangsungan pemerintahan regency, Suro Adimenggolo III meminta kepada VOC untuk memindahkan regency TulisLasem ke Magersari-Rembang (Unjia, 2014: 177).

Pindahnya regency bentuk VOC dari bumi Lasem itu tak membuat rakyat Lasem puas. Mereka menganggap selama VOC masih bercokol di Rembang, cakar kekuasaannya tetap mengancam kehidupan di sekitarnya. Seperti angin yang ditiupkan, semangat perlawanan terhadap VOC menggema di mana-mana.

Sampai pada sebuah peristiwa di hari Jum'at, kala Kyai Ali Baidhawi dalam khutbah Jumatnya di masjid kota menyerukan bahwa perang melawan kedzaliman yang dilakukan oleh bangsa asing kompeni Belanda adalah jihad fi sabilillah. Setelah adanya fatwa dalam khutbah tersebut, rakyat Lasem berbondong-bondong menjadi lascar perjuangan melawan penjajah dengan jumlah yang sangat besar. Semua lapisan masyarakat baik pribumi maupun etnis Tionghoa yang terdiri dari petani, nelayan, pedagang, ningrat, dan kaum santri bersatu menjelma menjadi kekuasan raksasa perjuangan (Unjia, 2014: 180).

Diawali di Pantai Bonang hingga pelabuhan Dasun, pertempuran terjadi antara laskar Lasem yang terdiri dari para santri dan orang-orang Cina di bawah komando Oei Ing Kiat behadapan dengan serdadu legion Rembang. Perang berkecamuk selama tiga bulan tanpa henti. Demam perlawanan terhadap kompeni Belanda pun menggema di mana-mana dan membuat desa-desa dan kademangan di sekitar Lasem dan Rembang menjadi terpanggil untuk ikut serta dalam perjuangan tersebut. Selama tiga bulan pertempuran itu mengakibatkan terjadinya ribuan nyawa dari kedua belah pihak yang melayang (Unjia, 2014: 180).

Meskipun akhirnya pertempuran itu dimenangkan oleh kompeni Belanda, solidaritas dan kerja sama antara warga pribumi Jawa dan etnis Tiongha terjadi dengan indah di tanah Lasem ini. Persaudaran antara orang Lasem merupakan warisan persaudaraan pahlawan Perang Kuning; Oei Ing Kiat, Panji Margono dan Kyai Baidhawi. Peristiwa bersejarah tersebut, mempunyai arti penting pada rakyat dewasa ini. Peristiwa itu merupakan simbol kepahlawanan dan persatuan dari pluralitas di Lasem antara kalangan santri pribumi, bangsawan dan abangan serta etnis Tionghoa yang monumental yang perlu diabadikan, diwariskan kepada anak cucu. Bahkan peristiwa itu diharapkan dapat menjadi muatan lokal sejarah daerah yang diajarkan di sekolah-sekolah di Lasem dan Kabupaten Rembang, menjadi pionir menuju kesadaran sejarah daerah dan nasional. 


\subsection{Relasi Sosial saling Membutuhkan}

Relasi antara etnis Tionghoa dan pribumi Lasem merupakan struktur sosial yang saling membutuhkan. Relasi ini terjadi pada wilayah elit dan masyarakat di perkampungan pada kehidupan seharihari. Pola hubungan antarelit terjadi pada komunikasi bersama dalam negosiasi, kontestasi maupun relasi yang saling membutuhkan. Negosiasi antarelit tampak pada kesempatan damai yang terjadi di Lasem untuk mengamankan kota pada isu kekerasan yang terjadi di akhir pemerintahan orde Baru. Negosiasisi ini menjadi titik tolak untuk melihat ancaman-ancaman terhadap harmoni di Lasem yang terjadi sebelumnya, yakni pada masa colonial VOC dengan reaksi perang kuning (Aziz, 2014: 144). Perang antara kaum santri, petani, nelayan Lasem bersama entis Tionghoa dalam melawan penjajah Belanda.

Dalam bidang ekonomi di level menengah tengah sampai atas, perekonomian Lasem dikuasi oleh warga keturunan Cina. Ini dapat dilihat banyaknya pertokoan disepanjang jalan jalan utama Lasem yang dimiliki dan dijalankan oleh warga keturunan Cina. Khusus bisnis level menengah, sejak sebagian warga keturunan Cina mengembangkan bisnisnya ke kota-kota besar seperti Jakarta, Semarang dan Surabaya, para warga pribumi kaum santri Lasem di antaranya mulai mengembangkan bisnisnya diberbagai macam sektor, terutama bisnis pakaian dan kebutuhan rumbah tangga.

Level tingkatan ekonomi di Lasem mengalami perubahan dari masa sebelum dan sesudah orde baru. Pasca runtuhnya Orde Baru, orang-orang Jawa mulai mengambil alih roda perekonomian dari tangan keturunan Cina, terutama di lokasi sekitar masjid Lasem (Pratiwo, 2010: 152). Toko-toko pakaian dan peralatan rumah tangga yang berada di
Taman Lasem hampir semuanya milik warga Jawa Lasem. Bahkan tercatat terdapat Mall kecil di perempatan Nashriyah yang dimiliki oleh orang Jawa meski bukan orang Lasem asli.

$$
\text { Hubungan antarelit yang }
$$

berlangsung pada lingkaran saling membutuhkan terjadi pada ritual budaya masing-masing kelompok. Ketika orang keturunan Tionghoa beserta komunitasnya menyelenggarakan perayaan Imlek, Cap Go Meh, maupun acara kirap budaya perayaan Mak Co di Klenteng, terjadi hubungan yang saling toleran, meski ada sebagian Kyai Lasem yang tidak sepakat acara tersebut, namun acara tersebut tetap berjalan lancar, bahkan perayaan tersebut melintasi masjid Jami' Lasem. Sebelumnya panitia sowan ke para Kyai yang dianggap simpul masyarakat di tiap daerahnya, seperti Gus Qoyyum, Gus Zaim dan lainnya. Komunikasi cultural ini untuk meminta restu agar keamanan terjamin, tidak ada kecurigaan dan acara dapat berjalan dengan lancar dan tertib ketika melintasi jalan jalan disekitar pesantren (Aziz, 2014: 145).

Di tingkat warga, dalam kehidupan sehari-hari harmoni terjaga karena beberapa faktor, yakni perkawinan silang, perasaan bersaudara antarwarga, hingga terbukannya ruang-ruang sosial. Perkawinan silang antarwarga lintas etnik yang terdiri dari orang Tionghoa, pribumi Jawa dan santri, terjadi sejak hadirnya orang Tionghoa di Lasem, sekitar abad XIII, kemudian dilanjutkan dengan kedatangan rombongan Cheng Ho di daerah binangun sekitar abad XV. Sejak saat itu, perkawinan campur lazim terjadi hingga kini (Aziz, 2014: 146).

\section{Nilai-nilai Toleransi Beragama di Lasem}

Secara etimologi toleransi berasal dari kata tolerare (Bahasa Latin) yang berarti saling menanggung dan memikul. 
Berarti toleran diartikan sebagai sikap saling memikul walau pekerjaan itu tidak disukai; atau memberi tempat kepada orang lain, walaupun kedua belah pihak tidak sependapat (Siagian, 1993: 115). Kata toleran ini lebih kentas unsur sosiologisnya daripada teologisnya (Purnama, 2002: 2). Dalam Kamus Umum Bahasa Indonesia, toleransi berasal dari kata "toleran" yang mempunyai padanan dalam bahasa Inggris tolerance. Toleransi dalam bahasa Arab adalah tasamuh, (Ibnu Mandzur, Maktabah Syamilah) berarti membiarkan sesuatu untuk dapat saling mengizinkan dan saling memudahkan. Toleransi juga mempunyai arti kesabaran, ketahanan emosional, dan kelapangan dada.

Dalam Al-Qur'an pun banyak konsep-konsep yang membicarakan tentang toleransi. Nilai-nilai toleransi alQur'an dibagi dua. Pertama, toleransi kepada sesama muslim, ini merupakan sebuah keniscayaan dan kewajiban wujud persaudaraan yang terikat oleh tali aqidah yang sama. Kedua, toleransi kepada non muslim, toleransi terhadap non muslim juga diperintahkan, karena islam mengajarkan perdamaian baik terhadap muslim dan non muslim. Konsep kerja sama dan toleransi hanya dalam kepentingan duniawi saja, tidak menyangkut kepentingan agama, seperti aqidah.

\subsection{Toleransi Sesama Muslim}

Dalam surat al-Hujurat ayat 10 , Allah menjelaskan bahwa orang-orang beriman itu bersaudara, oleh sebab itu sesama muslim harus pandai-pandai memperbaiki hubungan antara mereka. Dalam surat di atas Allah memerintahkan untuk melakukan ishlah (perbaikan hubungan) jika seandainya terjadi ketidak sepahaman antara dua orang individu maupun kelompok umat Islam. Maka dalam rangka mengembangkan sikap toleransi, dapat dimulai terlebih dahulu dengan bagaimana kemampuan seorang muslim dalam mengelola dan mensikapi perbedaan yang terjadi pada saudara kita sesama muslim. Sikap toleransi dimulai dengan cara membangun kebersamaan atau keharmonisan dan menyadari adanya perbedaan.

Lasem merupakan kota berkumpulnya berbagai macam etnis dan ormas. Di dalamnya terdapat berbagai ormas Islam yang hidup dengan rukun antar pengikutnya. Nahdlatul Ulama (NU) merupakan organisasi terbesar yang mempunyai warga yang mayoritas di Lasem. Selain itu ada Muhammadiyah, FPI, HTI dan Jam'iyah Tabligh (JT). Pluralitas ormas yang ada di Lasem berjalan dengan baik. Mereka hidup saling menghormati dan melengkapi, bahkan beberapa kali para pengurus antar ormas tersebut mengadakan pertemuan keakraban dan persaudaraan dalam sebuah wadah organisasi Majlis SILMI (Silaturrahim Umat Islam Lasem).

Kaum muslimin Lasem termasuk kelompok egaliter atau menerima dengan baik pemikiran dan keberadaan pendatang baru sesama muslim. Bahkan ini sudah terjadi awal kedatangan Islam di Lasem, sejak Mbah Sambu atau Sayyid Abdurrohman. Melalui Mbah Sambu yang merupakan pendatang ini Islam menyebar di Lasem dan sekitarnya. Mbah Sambu sebagai seorang pendatang diperlakukan dengan baik oleh warga Lasem bahkan diambil menantu oleh Mbah Srimpet (Adipati Lasem Tedjokusumo). Bahkan masjid yang berada di tengah-tengah kota Lasem dinamakan dengan masjid Baiturrahman yang di sebelahnya terdapat makam Mbah Sambu.

Fakta lain yang tidak terbantahkan oleh masyarakat Lasem adalah mereka menerima dan mempersilahkan para pendatang untuk menduduki posisi-posisi strategis dalam masyarakat. Mereka mempersilahkan para pendatang yang ingin berkhidmat dan memberikan pencerahan-pencerahan di masyarakat 
Lasem. Di antara posisi-posisi strategis dalam masyarakat adalah seperti posisi sebagai ketua NU, pengurus Masjid Jami', sebagai Kyai di pondok pesantren dan lain-lain. Kedua PCNU Lasem diketuai kepada H. Sholahuddin Fatawi yang berasal dari Gresik Namun telah menetap lama di Lasem. Rois Syuriyah MWC NU Lasem diserahkan kepada $\mathrm{H}$. Ahmad Atabik yang berasal dari Pati. Ketua Ta'mir masjid Jami' Lasem diemban oleh H. Abdul Muid yang berasal dari Pamotan.

Sikap masyarakat Lasem mempersilahkan kepada para pendatang untuk turut serta membangun dan menduduki posisi strategis dalam masyarakat pernah juga dipraktikkan oleh kaum Anshor (penduduk Madinah) kepada para pendatang (kaum muhajirin Makkah). Kaum Anshor memberikan vasilitasvasilitas dan posisi-posisi strategis kepada kaum Muhajirin dalam membangun negara Madinah. Hal ini terekam dalam al-Qur'an QS. Al-Hasyr: 9:

"Dan orang-orang yang telah menempati kota Madinah dan telah beriman (Anshor) sebelum (kedatangan) mereka (Muhajirin), mereka (Anshor) 'mencintai' orang yang berhijrah kepada mereka (Muhajirin). Dan mereka (Anshor) tiada menaruh keinginan dalam hati mereka terhadap apa-apa yang diberikan kepada mereka (Muhajirin); dan mereka mengutamakan (orangorang Muhajirin), atas diri mereka sendiri, sekalipun mereka dalam kesusahan. Dan siapa yang dipelihara dari kekikiran dirinya, mereka itulah orang orang yang beruntung. "

\subsection{Toleransi Muslim dengan Non Muslim \\ Sejarah persaudaraan Perang Kuning telah merekatkan masyarakat}

Lasem baik penduduk asli yang mayoritas muslim dengan etnis Cina yang non muslim.

Dalam kehidupan keseharian, hubungan kerja sama saling membutuhkan juga terjadi antara orang Tionghoa dengan pribumi Jawa dan santri. Meskipun pengusaha Tionghoa mayoritas sebagai majikan, akan tetapi hal ini tidak menjadi instrument utama tentang dominasi orang Tionghoa di Lasem, dan sebaliknya ketertundukan ekonomi pribumi Jawa dan Santri.

Hubungan sosial antara orang Tionghoa dan santri di Lasem terjalin dengan baik. Perasaan persaudaraan dipadu dengan kenyataan sosial berupa perkawinan silang antara etnis Cina dengan Jawa. Kyai Mazid yang menikah dengan perempuan Tionghoa, dan Thiam Pie yang menikah dengan perempuan pribumi Jawa merupakan lembaran kisah tentang hubungan perkawinan warga lintas entis di Lasem. Dari ilustrasi di atas, hubungan sosial antara orang Tionghoa dan santri di Lasem berimplikasi pada terjaganya nilai keharmonisan di antara warga Lasem. Selain itu juga tercerminkan nilai-nilai toleransi yang terdapat pada masyarakat Lasem antara penduduk asli dan etnis Cina.

Kebersamaan yang terpadu dalam hubungan harmonis dalam narasi Perang Kuning merupakan basis ingatan untuk menjaga relasi damai antarwarga Lasem. Hubungan harmonis itu terjaga di kalangan elit Tionghoa (pengusaha dan pengurus organisasi), dan elit santri (kyai dan pengasuh pesantren) untuk menjaga komunikasi dan meredam ancaman kekerasan.

Menarik apa yang diungkapkan oleh Sie Hwie Djan ketika diwawancai terkait dengan sikap toleransi orang Tionghoa dengan warga Jawa di Lasem, sebagai berikut: 
"Kita ini orang Timur, dan kita hidup di tanah Jawa. Dan kita ini berpedoman pada adat tanah Jawa. Ini kita ambil gaibnya dulu, lalu manusianya. Manusia kalau tanpada pandangan terhadap gaibnya, tidak lengkap. Di Lasem, secara budaya Tionghoa, itu sudah habis oleh barat, timur, utara dan selatan. Yang menghadap timur, ada masjid Agung. Yang menghadap Barat ada $\mathrm{Cu}$ Angh Kiong, yang menghadap Selatan, ada Po An Ging, yang ke Utara ada Klenteng Babagan. Ini secara gaib, hawa yang jahat sulit masuk. Barometer untuk suhu politik ada di Lasem. Kalau Lasem pecah, maka ambyar. Boleh dibilang, sa Jawa Tengah. Untungnya generasi penerus, saya ambil contoh yang dengan saya, Mbah Ma'shum, itu Kyai Besar, sebelum ada Kyaikyai yang belum kyai sudah menamakan kyai, itu banyak di sini." (Aziz, 2014: 158).

Santoso, seorang tokoh Tionghoa di Lasem, mengungkapkan bahagianya menjadi pendatang di Lasem, dengan suasana harmoni dan saling menghargai. Ia menyatakan begini:

"Dalam sejarahnya interaksi orang china (kristen dan konghucu) dan pribumi (muslim) sangat cair dan dinamis. Bahkan perkawinan silang lintas etnis sudah sangat biasa di Lasem. Dalam sebuah keluarga sangat biasa terdapat pluralitas agama. Meskipun saya punya 300an karyawan, hampir seluruhnya muslim, namun saya tidak pernah menyuruh mereka keluar dari Islam, bahkan saya sediakan musholla di rumah saya. Dalam kegiatan-kegiatan keagamaan
Islam saya sering mewarnai dengan memberi bantuanbantuan.

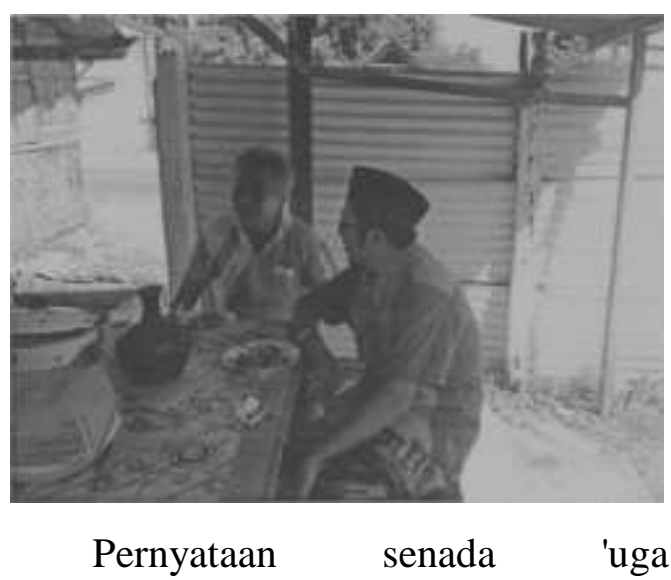
disampaikan oleh Bul Hong, tokoh Tionghoa di Lasem, betapa indahnya hidup di Lasem, sebagai berikut:

Kemajemukan masyarakat Lasem sangat indah, dan rukun. Hal ini yan tidak saya ditempat lain. Tidak ada bedanya di sini orang kaya dengan orang miskin, orang pribumi maupun pendatang. Semua saling menghargai. Saya sering mengadakan kegiatan rutin dengan pribumi untuk mempromosikan Lasem sebagai kota heritage (warisan) dunia. Saya turut mensponsori kegiatan2 tersebut. Kami warga pribumi dan keturunan china ingin mengembalikan kejayaan Lasem, sebagai kota warisan dunia. Prinsip saya dalam kehidupan yang beragama ini adalah berlomba-lomba dalam kebaikan, sesuai dengan hal-hal yang saya yakini. Dan itulah ajaran nenek moyang saya." 


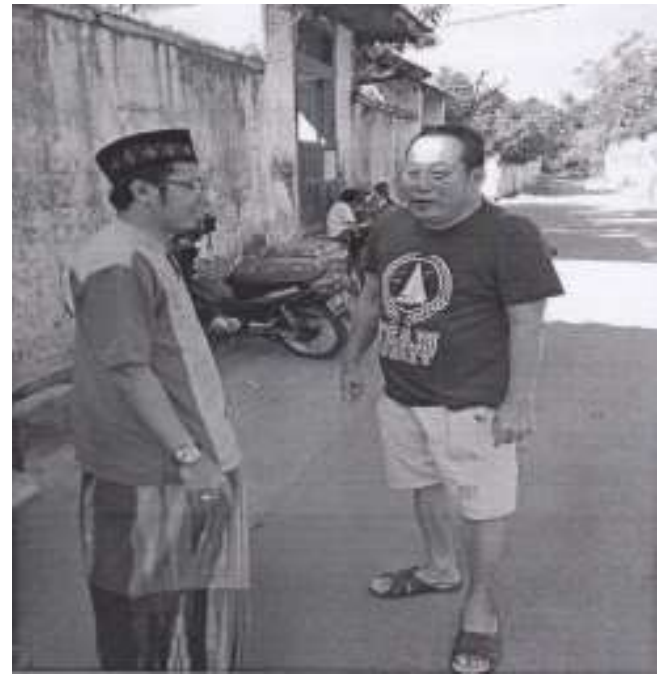

\section{Simpulan}

Sejarah telah mencatat interaksi sosial yang terjadi antara masyarakat Lasem pribumi dengan etnis Cina, sejak abad 14 hingga abad 16. Meskipun interaksi kedua etnis tersebut mengalami pasang surut, namun harmoni dan toleransi itu senantiasa berjalan dengan baik.

Kedatangan etnis Cina di Lasem melahirkan kebudayaan dan pluralitas dalam masyarakat. Pluralitas itu membentuk sebuah harmonisasi kerukunan dalam beragama dan bersosial. Hubungan yang harmonis antara kedua etnis tersebut terutama ketika bersamasama melawan penjajah Belanda di bumi Lasem. Harmoni dan toleransi masyarakat muslim Lasem juga dapat lihat dari interaksi penduduk asli secara baik dengan para pendatang, baik yang beragama muslim maupun non muslim yang kebanyakan dari etnis Cina.

Dalam kehidupan sehari-hari, harmoni terjaga karena beberapa faktor, yakni perkawinan silang, perasaan bersaudara antarwarga, hingga terbukannya ruangruang sosial. Perkawinan silang antarwarga lintas etnik yang terdiri dari orang Tionghoa, pribumi Jawa dan santri, terjadi sejak hadirnya orang Tionghoa di Lasem.

\section{Daftar Pustaka}

Aziz, Munawir. 2014. Lasem Kota Tiongkok Kecil: Interaksi Tionghoa, Arab dan Jawa dalam Silang Budaya Pesisiran. Yogyakarta: Ombak.

Handinoto dan Samuel Hartono. 2006. "Lasem: Kota Kuna yang bernuansa China". Seminar Nasional Pemahaman Sejarah Arsitektur Indonesia X, Arsitektur Pecinan di Indonesia. Jurusan Unika Soegijapranata Semarang.

Handinoto. 2015. Lasem: Kota Tua Bernuansa Cina di Jawa Tengah. Yogyakarta: Ombak.

Komunitas Rumah Buku Lasem. 2014. Lasem: $\quad$ Sejarah Panjang Toleransi. Lasem: Elzam Berkah Utama.

Mandzur, Ibnu. Lisan al-Arab, Lafaz Tasamuh berasal dari maddah sama-ha. Maktabah Syamilan.

Pratiwo. 2010. Arsitektur Tradisional Tionghoa dan Perkembangan Kota. Yogyakarta: Ombak.

Purnomo, Aloys Budi. 2013. Membangun Teologi Inklusif - Pluralistik, Jakarta: Kompas.

Rahman, Budhi-Munawar. 2001. Islam Pluralis. Jakarta : Paramadina.

Siagian, SH. 1993. Agama-agama di Indonesia, Semarang: Satya Wacana.

Unjiya, M. 2014. Lasem Negeri Dampo Awang. Yogyakarta: Salmaidea.

http://suaramerdeka.com/v1/index.php/re ad/cetak/2010/07/17/117125/Bona ng-Lasem-dan-Keberagamandiakses pada tanggal 20 Juli 2015. 